\title{
The phenomenon of «man between life and death" in the space of the Nazi concentration camp
}

\author{
S.A. Voronin, B.G. Yakemenko \\ Peoples' Friendship University of Russia (RUDN University) \\ 6 Miklukho-Maklay St., Moscow, 117198, Russia
}

The article explores the phenomenology of a special category of prisoners of Nazi concentration camps, who were in a state close to death, but for a long time did not die, being in a special, borderline state of mind and body. In camp jargon, they were called "Muslims", which was not related to religious confession - the etymology of the term is controversial. The state in which the "Muslims" were, is an unknown phenomenon, since it is characterized by almost complete fading of mental and physical functions, the Erasure of age and sex characteristics. This category of prisoners can be considered the apotheosis of the Nazi concentration camp system.

Keywords: concentration camp, "Muslim", body, absolute evil, pain, suffering, phenomenology

Nazi concentration camps have become one of the most tragic episodes in the history of the past century. Traditionally, they are perceived as places where people were punished and killed, like places of detention similar to ordinary prisons, but more cruel and inhuman. In fact, the concentration camps were an unprecedented attempt to create a fundamentally new territory of human existence within the boundaries of death, an area where all existing norms and rules were radically abolished.

Concentration camps were a system that for the first time in the history of humankind produced death, and people served as raw materials for its production. As a result, the concentration camps provided the absolute totality of the Nazi state, it was in the camps that this totality was sublimated, which permeated everything from ascent to rebound, the entire structure of the prisoner's life reflected the symbolic system of the totalitarian state and indicated to them their place in this system, on its lowest tiers. In this case, the totality was the more absolute, the more people fell into the camps and the harder was the treatment with them.

(C) Voronin S.A., Yakemenko B.G., 2019 
In the Concentration World violence replaced history next to mythology (violence is one of the main means of turning history into mythology), becoming the main driving force of the Nazi state. The violence used initially as a mean in the Concentration World became the goal, the essence, and the circulatory system of the Nazi state. The unprecedented violence was largely as it was a perceived consequence of the state's extreme pressure on society. Because of this pressure, a fundamentally new category of people should have crystallized (as under extreme pressure, graphite turns into diamond), which will ensure the irreversibility of time. It is not by chance that the construction of a "new person", the search for new opportunities for a person, which resulted in savage experiments on people in the Concentration World, permeate the whole ideology of the Third Reich.

Over 10 years of their existence, millions of people passed through the Nazi concentration camps, most of whom died. Inhuman torments, violence, hard labor, the daily death of prisoners led to the fact that the camps imprisoners came to a biological and psychophysical state, an analogue of which is difficult to find. The apotheosis of the prisoner's stay in the Nazi concentration camp was the condition described in the camp jargon by the term "Muslim" (Muselmänn). "I saw strange creatures that at first even puzzled me a little, - as one of the prisoners testified, - at a distance, they all looked like ancient elders: a protruding nose, a head pulled in the shoulders, a dirty striped robe hanging on the sharp shoulders, like on a hanger; even on the hottest summer days they looked like frozen winter crows.

In each of their unsure, lunatic step, it was as if they asked: was it really worth this incredible effort? These walking question marks - even if you look at the figure, even at the volume (you can say they didn't have thickness at all), I can't describe them differently - were called 'Muslims' in the camp, as I soon externally learned [1], the Muslim was a man who had reached an extreme degree of exhaustion, that is, weighed $35-40 \mathrm{~kg}$, was emaciated into a skeleton and moved with difficulty. He had erased sex and age limits and internally he was in a state of almost complete fading of the psyche. Normal interest in the environment disappeared in him more and more, so that in the end interest in his own destiny went out. In this condition, a Muslim imperceptibly died - he simply fell asleep and did not wake up" [2. Pp. 64-65].

There is no unity of opinion where the term itself came from. The purpose of this article does not include a detailed examination of its etymology, therefore it should be indicated only that according to one of the versions the German word muselmänn in relation to this category of prisoners is a distortion of the word muschelmann/musselman, that is, "crooked man" (women were called Muselweib (Weib - it is a derogatory "woman")). Another version connects the origin of the term with the image of real praying Muslims. "They (Muslims) became indifferent to everything that happened around them. They put themselves outside of any relationship with the outside world. If they could still move, they did it slowly, without bending their knees. They were shaking from the cold.... Looking at them from the side, it seemed as if they were praying Arabs" [3. P. 94]. The point of view about the alleged resemblance of the worshiping followers of Islam and the 
camp Muslims is supported W. Sofsky [4. P. 329] G. Agamben [5. P. 45], B. Bettelheim [6. P. 77] and O. Kogon [7. P. 284]. They associate the emergence of the term with the fatalism allegedly inherent in the followers of Islam, which was characteristic of camp Muslims. It is necessary to make a reservation that we will use this term in the work without quotes, since it will be used only in the meaning indicated above.

It is curious that a Muslim, as a sublimation of an inhabitant of the "concentration world", almost did not become the subject of a special study, although to understand the Muslim phenomenon in the camp would obviously mean to approach to the understanding of the "concentration world" as a whole. Today, there is a sole monograph that explores the Muslim phenomenon in a concentration camp, written by Z. Ryn and S. Klodzinski [3. P. 94] ("At the border between life and death: a study of the phenomenon of the Muselmann in the concentration camp"). Part of D. Agamben's work is also devoted to this phenomenon [5. P. 45]. Other works are mostly descriptive, with memoir character and some attempts of analysis.

The Muslim in the camp environment was considered extremely dangerous, people tried to avoided him, because their condition and they themselves were generally incomprehensible to either the rest of the prisoners or the guards, however, both of them felt that is a Muslim, has a attracting effect, attractive and at the same time destructive force. "Nobody sympathized with Muslims, and no one felt sympathy for them. Other prisoners who constantly feared for their lives did not even consider them worthy of their eyes... Everyone would like to destroy them, each in his own way" [3. P. 127]. "Bandi Zitrom immediately warned me: stay away from them. 'You look at them and you want to hang yourself,' he said, and there was a large share of truth in his words" [1], - recalled I. Kertes. B. Bettelheim wrote, "Any contact with a 'marked' (Muslim) could only lead to self-destruction" and explained the fear of Muslims that other prisoners were afraid to become [6. Pp. 76-77].

However, it is impossible to explain the fear of Muslims only by a sense of self-preservation - often silent, bent, shuffling Muslim prisoners were afraid more than screaming and cursing SS men with weapons and capos with clubs, more than the dead. "Muslim is even worse than stacks of the dead" [8. P. 211], - reflected Y. Tsurkan. Another prisoner recalled: "We were all afraid of this state of absolute emptiness, and we all hoped that death, if it happens, will take us away before the same fate befalls us" [9. P. 50].

The fear of Muslims, obviously, was associated with an awareness (sensations) of a fundamentally different nature, a different state, a Muslim. What did the genesis of this state look like?

All researchers and direct observers of Muslims noted that the state, in which the Muslim was, formed the inner world, unlike other prisoners, whose condition was largely dependent on the external environment.

In this case, it is appropriate to compare with the extreme degree of physical dystrophy or anorexic state, when the human body consumes itself, not needing external sources of energy, which leads to death. A Muslim is a person who has come to the state of mental malnutrition, when the totality of suffering, pain, hunger 
pangs, moral and psychological exhaustion is his essence, completely replaces the personality, when "non-physical malnutrition" is a person, or rather what is considered to be. D. Agamben noted that "a Muslim is a moving border, having crossed that person ceases to be a man" [10. P. 49].

B. Bettelheim believed that a Muslim is the result of the treatment of a person by the camp environment. Therefore, the researcher attached great importance to the suppression of his own will in the person and believed that the prisoner took the first step to the state of the Muslim when he "stopped acting on his own will". The cessation of actions "from oneself", that is, spontaneity coincided with the appearance of a characteristic shuffling gait by which a Muslim was recognized from afar. The last thing that disappeared in a person before his final transformation into a Muslim was the ability to look around. After this, physical death occurred [6. P. 76].

The remark about the refusal of the ability to look around confirms the thesis stated above about the prevalence of the inner over the external in nature Muslim. "Closing" for external influences of sight meant that the sublimated from the above-described traits of evil finally passed from the external to the inner world of the Muslim, having reached its ultimate concentration. There was no such pain, torment, ordeals, forms of violence, which could add at least something to this embodied experience of evil. As soon as life in its own shell became worse for a Muslim than life in the camp, he passed the point of no return.

Thus, a Muslim can be described as a person in whom the concentration world has come true, he is the apotheosis and the highest achievement of this world, the result of the ultimate action of absolute evil in the world, the embodiment of this evil. Moreover, if we do not understand that this embodied, sublimated evil due to the included mechanisms of "non-physical asteno-anorexia" was directed inside the Muslim himself, we risk putting a number of Nazi leaders, creators of the concentration world, and Muslims. In the first case, this evil consciously, with the help of a strong, as L.N.Gumilyov would say, "long" will, was directed outwards, it was largely formed and maintained by the force of this will. In the case of the Muslim, this evil was the result of a complete, absolute lack of will, the fading of any impulses of the personal beginning, it absorbed all that was human in the Muslim, without releasing anything outside, like a black hole. At the same time, the worn Muslim flesh turned out to be a sufficient barrier to the release of this evil. Therefore, P. Levi was right, when he wrote that "if I could conclude all the evils of our time in one image," P. Levi wrote, "I would choose the image that I know so well: a devastated person with a fallen head and crooked shoulders, on whose face not a single thought can be seen" [11. P. 56].

The result of this process was that the Muslim was in the intermediate, third, previously unknown state of the biological being. It was a special form of the existence of human matter, which is possible only within the framework of camp borders. In the Muslim, the ultimate image of a man was revealed, in which any criteria and boundaries are abolished, that is, he stands at the turn of the human and inhuman. He cannot be described even as a living person, for even the signs of biological life, expressed in external reactions, are reduced to almost indistinguishable values. 
Muslim does not feel pain, does not suffer when violence is applied to him, does not feel hunger and thirst, all feelings (that is, signs of life) are muffled in him.

Muslim is "too empty to really suffer" [12. P. 149]. "You need to raise your voice so that such a person can hear you, come close, so that he can see you" [8. P. 211]. However, he also cannot be described as a corpse, because, according to the recollections of eyewitnesses, a Muslim is worse than a corpse, it was impossible to look at him, unlike a dead man. "The third dimension of a Muslim is an absolute cipher of camp life, a 'non-place' in which all disciplinary barriers are destroyed and all embankments are flooded" [5. P. 48]. The uniqueness and incomprehensibility of a Muslim is that he manages to stay for hours/days/months on an elusive, unexplained, thinner time, the boundary between life and death, between a living body and a corpse, between human and non-human, on which any other person does not. He can hold on for a few seconds in order not to fall in one direction or the other. The incomprehensibility of such a phenomenon as a Muslim forced some researchers to try to penetrate into their essence in the logic of paradox. E. Fackenheim argued that the Muslim of the Concentration World "is the most remarkable, if not the only, contribution of the Third Reich to world civilization. It has become a true innovation of the New Order". According to Fackenheim "the uniqueness of a Muslim makes us consider unique and those who managed to turn a person into a Muslim and raises the question "Could Jesus of Nazareth be turned into a Muslim?" [13. Pp. 215-273]. We should not try to answer the rhetorical question, but we should pay attention to the fact that Fackenheim accurately determined the coordinate in which the concentration world existed - from the SS to Muslim, from antiman to non-human. The apotheosis of violence and the apotheosis of lack of will, when a Muslim and an SS man cannot exist without each other, are a necessary condition for mutual existence. It is impossible not to emphasize that the inner world of the nominal SS man who created the concentration world and ensured its existence is as incomprehensible to the end as the Muslim world is an unsolvable task with many unknowns.

The coincidence of the human and the non-human in the Muslim, their mixing to the utterly indistinguishable, made the Muslim an aporia of the concentration world. The emergence of the Muslim became a sign that in the concentration world the distinctions between being and non-being, permissible and impossible, finally disappeared, that is, a different kind of existence that cannot be defined in the usual categories. "The extermination camps," wrote D. Agamben, "represent an attempt to resolve the issue of the distinction between human and non-human, which ultimately destroyed the very possibility of such distinction" [10. P. 33].

In conclusion, one should pay attention to the fact that the Muslims, despite the disgust at them of both the other prisoners and the camp administration, with their almost complete inability to work, were not exterminated by the camp administration deliberately. Throughout the years of existence of the concentration world, they remained an integral part of the camp system. This suggests that their state, appearance, were a necessary condition for the existence of a concentration world, a condition that maintains balance and relative "harmony" of the parts, each of which was in its place. Otherwise, Muslims would be rejected or co-opted by the system. 


\title{
REFERENCES
}

[1] Kertesz I. Fatalessness. http://detectivebooks.ru/book/1744658/

[2] Concentration camp Auschvits-Birkenau. Comp. by Yan Zen. Warsaw, 1957.

[3] Ryn Zdzislaw, Klodzinski Stanslav. "An der Grenze zwischen Leben und Tod. Ein Studie über die Erscheinung des 'Muselmann' in Konzentrationslager" // Auschwitz-Hefte. Vol. 1. Weinheim \& Basel: Beltz, 1987.

[4] Sofsky $W$. The Order of Terror: The Concentration Camp / Translated by William Templer. Princeton University Press, 1997.

[5] Agamben D. The remnants of Auschwitz: the Witness and the Archive / Translated by Daniel Heller-Roazen. Zone Books, New York, 1999.

[6] Bettelheim B. The informed heart // Chelovek. 1992. No. 2. (In Russian)

[7] Kogon E. The Theory and Practice of Hell: The German Concentration Camps and the Systems Behind Them / Translated by Heinz Norden. Octagon Books, New York, 1979.

[8] Tsurkan Y. Last circle of hell. Moscow, 2017. (In Russian)

[9] Doerr K. Words of Fear, Fear of Words: Language Memories of Holocaust Survivors // Explorations in Anthropology. 2009, February. Vol. 9. No. 1.

[10] Agamben $V$. The open: man and animal. Moscow, 2012. (In Russian)

[11] Levi P. The Drowned and the Saved. Moscow, 2016.

[12] Patterson D. Open wounds: The Crisis of Jewish Thoughts in the Aftrrmath of the Holocaust. Seattle: University of Washington Press, 2006.

[13] Fackenheim E. To Mend the World: Foundations of Post-Holocaust Jewish Thought. Schocken Books, New York, 1982.

Научная статья

\section{Феномен «мусульманина» в пространстве нацистского концентрационного лагеря}

\author{
С.А. Воронин, Б.Г. Якеменко \\ Российский университет дружбы народов \\ Россия, 117198, Москва, ул. Миклухо-Маклая, 6
}

В статье исследуется феноменология особой категории заключенных нацистских концентрационных лагерей, которые находились в состоянии, близком к смерти, однако в течение долгого времени не погибали, находясь в особом, пограничном состоянии психики и тела. На лагерном жаргоне они именовались «мусульмане», что не было связано с религиозным исповеданием - этимология термина спорна. Состояние, в котором находились «мусульмане», является непознанным феноменом, так как характеризуется практически полным замиранием психических и физических функций, стиранием возрастных и половых признаков. Эту категорию узников можно считать апофеозом системы нацистских концентрационных лагерей.

Ключевые слова: концентрационный лагерь, «мусульманин», тело, абсолютное зло, боль, страдания, феноменология 


\section{Информация об авторах / Information about the authors}

Воронин $\boldsymbol{C}$.A., д.И.н., заведующий кафедрой всеобщей истории РУДН, директор Центра исторической экспертизы и государственного прогнозирования. E-mail: Voronin_ sa@rudn.ru

Якеменко Б.Г., к.и.н., доцент кафедры истории России РУДН, заместитель директора Центра исторической экспертизы и государственного прогнозирования. E-mail: yakemenko-bg@rudn.ru

Voronin S.A., Doctor of History, Head of the Department of General History of RUDN University, Director of the Center for Historical Expertise and State Forecasting. E-mail: Voronin_sa@rudn.ru

Yakemenko B.G., PhD (in History), Associate Professor of the Department of Russian history, Peoples ' Friendship University of Russia, Deputy Director of the Center for Historical Expertise and State Forecasting. E-mail: yakemenko-bg@rudn.ru

\section{Для цитирования / For citation}

Воронин С.А., Якеменко Б.Г. Феномен «мусульманина» в пространстве нацистского концентрационного лагеря // Вестник Российского университета дружбы народов. Серия: Всеобщая история. 2019. Т. 13. № 3. С. 195-201.

Voronin S., Yakemenko B. The phenomenon of "man between life and death" in the space of the Nazi concentration camp // RUDN Journal of World History. 2019. Vol. 13. No. 3. Pp. 195-201.

Рукопись поступила в редакцию / Article received:

22.06.2019 